\title{
Anti-inflammatory, pro-apoptotic, and anti-proliferative effects of a methanolic neem (Azadirachta indica) leaf extract are mediated via modulation of the nuclear factor- $\kappa$ B pathway
}

\author{
Marc Schumacher • Claudia Cerella . \\ Simone Reuter • Mario Dicato • Marc Diederich
}

Received: 22 July 2010/Accepted: 20 November 2010/Published online: 14 December 2010

(C) Springer-Verlag 2010

\begin{abstract}
Azadirachta indica (neem tree) is used in traditional Indian medicine for its pharmacological properties including cancer prevention and treatment. Here, we studied a neem extract's anti-inflammatory potential via the nuclear factor- $\kappa \mathrm{B}(\mathrm{NF}-\kappa \mathrm{B})$ signaling pathway, linked to cancer, inflammation, and apoptosis. Cultured human leukemia cells were treated with a methanolic neem leaf extract with or without tumor necrosis factor (TNF)- $\alpha$ stimulation. Inhibition of NF- $\kappa \mathrm{B}$ activity was demonstrated by luciferase assay and electrophoretic mobility shift assay (EMSA). Inhibition of viability by neem extracts was assessed by luminescent assays. Western blot analysis allowed assessing the inhibitory effect of the neem extract on TNF- $\alpha$-induced degradation of inhibitor of $\kappa \mathrm{B}(\mathrm{I} \kappa \mathrm{B})$ and nuclear translocation of the NF- $\kappa$ B p50/p65 heterodimer. Inhibition of $\mathrm{I} \kappa \mathrm{B}$ kinase (IKK) activity was shown as well as the effect of neem extract on the induction of apoptotic cell death mechanisms by nuclear fragmentation analysis and flow cytometry analysis. In conclusion, our data provide evidence for a strong effect of the neem extract on proinflammatory cell signaling and apoptotic cell death mechanisms, contributing to a better understanding of the mechanisms triggered by Azadirachta indica.
\end{abstract}

Marc Schumacher and Claudia Cerella contributed equally to this work.

M. Schumacher $\cdot$ C. Cerella $\cdot$ S. Reuter $\cdot$ M. Dicato

M. Diederich $(\square)$

Laboratoire de Biologie Moléculaire et Cellulaire du Cancer,

Hôpital Kirchberg, 9, rue Edward Steichen, L-2540

Luxembourg, Luxembourg

e-mail: marc.diederich@lbmcc.lu
Keywords Azadirachta indica $\cdot$ Methanolic neem leaf extract · Nuclear factor-kappa B · Inflammation · Apoptosis

\section{Introduction}

The evergreen neem tree (Azadirachta indica) exhibits several activities useful for agricultural and medicinal applications known in India for thousands of years. The plant or its preparations are extensively reported to exert insecticidal, pesticidal, and agrochemical properties. Additionally, its constituents are applied in alternative (Ayurveda, Unani, Homeopathy) and modern medicine, e.g., for the treatment of diverse infectious, metabolic, or cancer diseases [11, 28] (for chemical structures, see Scheme 1).

In this context, azadirachtin 1, a tetranortriterpenoid extracted from neem seeds over 40 years ago [12], was shown to act as a potent phagorepellent and growth inhibitor of insects [53]. Neem tree constituents exhibit various multi-targeted biological activities, such as antibacterial [63], hypoglycemic [39], anti-ulcer [45], antimalarial [33], hepatoprotective [8], spermicidal [4], anti-inflammatory $[9,44,66]$, chemopreventive $[15,62]$, and chemotherapeutic [23, 24, 41] properties. Additionally, the nutritional potential of neem oil was evaluated by Rukimini [50].

Related to cancer, Arivazahagan and coworkers suggest that neem leaf extract may exert its chemopreventive effects by down-regulation of lipid peroxidation, simultaneously increasing the level of glutathione (GSH) and GSH-dependent enzymes [6]. The strong chemopreventive activity of the extract could additionally be confirmed in vivo in rodents $[22,58]$. Neem extract was able to induce apoptosis and to inhibit proliferation in prostate cancer 
Scheme 1 Chemical structures and biological activity of natural products isolated from the neem tree

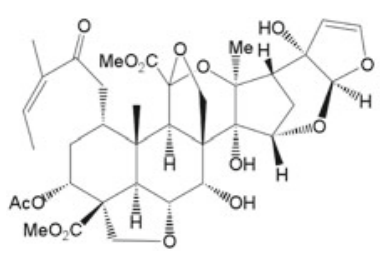

1 Azadirachtin

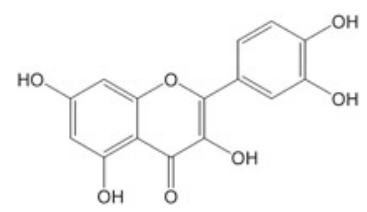

4 Quercetin

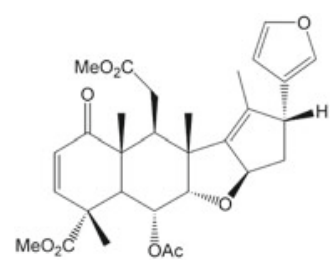

2 Nimbin

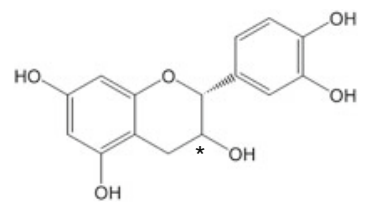

5 Catechin $\quad\left({ }^{*}=\mathrm{S}\right)$

6 Epicatechin $\left({ }^{*}=\mathrm{R}\right)$

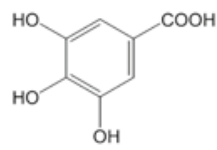

3 Gallic acid

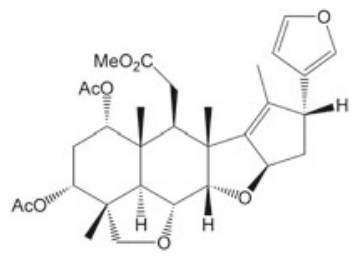

7 Salannin
[29]. This anti-proliferative effect might partially be due to nimbolide, a triterpene extracted from neem flower that was highly effective in several cancer cell lines, e.g., U937, HL-60, THP1, B16, and BoWe [23, 48]. Moreover, the leaf extract stimulates the immune function by the activation of killer cells [10]. Antioxidative activities were described for gallic acid 3, catechin 5, and epicatechin $\mathbf{6}$ extracted from the bark [66]. The antioxidative effect is mainly relied on the total content of phenolic compounds (e.g., flavonoids such as quercetin 4) [59]. Molecular mechanisms largely remain to be elucidated.

The NF- $\kappa \mathrm{B}$ transcription factor plays an important role in cancer and related diseases [56]. This transcription factor is localized in the cytosol and is blocked by inhibitor of $\kappa \mathrm{B}$ $(\mathrm{I} \kappa \mathrm{B})$. Upon activation by pro-inflammatory cytokines or viruses, phosphorylation of $\mathrm{I} \kappa \mathrm{B}$ by $\mathrm{I} \kappa \mathrm{B}$ kinase complex (IKK) is observed. After ubiquitinylation of $\mathrm{I} \kappa \mathrm{B}$, the latter is degraded resulting in the translocation of NF- $\kappa$ B to the nucleus. Here, the activated factor regulates the transcription of multiple genes responsible for regulation of cell cycle, apoptosis, or cellular invasion [17, 27]. Moreover, inhibition of NF- $\kappa$ B-regulated genes potentiates apoptosis $[3,5]$. This study gives first mechanistic insights into the inhibitory effect of a methanolic neem leaf extract (NLE) on the NF- $\kappa \mathrm{B}$ signaling pathway and subsequent induction of apoptosis in human leukemia cancer cell lines.

\section{Materials and methods}

Materials and cell culture

Tumor necrosis factor- $\alpha$ (TNF- $\alpha)$ purchased from Sigma was dissolved in $10 \mu \mathrm{g} / \mathrm{ml}$ in PBS $(1 \times)$ supplemented with $0.5 \%(\mathrm{w} / \mathrm{v}) \mathrm{BSA}$ according to manufacturer's instructions.
Quercetin, gallic acid, catechin, and epicatechin were purchased from Sigma. Salannin and nimbin were purchased from Trifolio GmbH. K562 (human chronic myeloid leukemia in blast crisis) and Jurkat (human T-cell leukemia) and U937 (human histiocytic lymphoma) cells were obtained from (DSMZ) Deutsche Sammlung von Mikroorganismen und Zellkulturen $\mathrm{GmbH}$ and were maintained in RPMI medium (Bio-Whittaker) with $10 \%$ $(\mathrm{v} / \mathrm{v})$ fetal calf serum (FCS) (Bio-Whittaker) and 1\% (v/v) antibiotic-antimycotic solution (Sigma) in an incubator $\left(37^{\circ} \mathrm{C}, 5 \% \mathrm{CO} 2\right)$.

Healthy blood samples were kindly donated as buffy coats by the Red Cross (Luxembourg, Luxembourg). By applying diluted (1/3) blood onto a Ficoll layer followed by centrifugation $(400 \mathrm{~g}, 20 \mathrm{~min})$, mononuclear cells were isolated and collected. The isolated peripheral blood mononuclear cells (PBMCs) were kept in culture at $37^{\circ} \mathrm{C}$ and $5 \% \mathrm{CO}_{2}$ for $24 \mathrm{~h}$ before they were subjected to treatments.

Preparation of the neem leaf extract

Dried leaves of the neem tree were grinded in a mortar. The resulting green solid powder was dissolved in methanol, and the suspension was mixed in a shaker at $25^{\circ} \mathrm{C}$ for $24 \mathrm{~h}$. Then, remaining powder particles were removed by filtration, and the solvent of the green methanolic solution was evaporated to dryness yielding a green crude extract (yield: $13.2 \% \mathrm{~m} / \mathrm{m}$ of the starting material). This crude extract was dissolved in dimethyl sulfoxide (DMSO) at a concentration of $80 \mathrm{mg} / \mathrm{ml}$ and stored at $-20^{\circ}$.

\section{HPLC analysis}

An Agilent 1200 HPLC system with a DAD UV-VIS detector was used. The separation was performed on a 


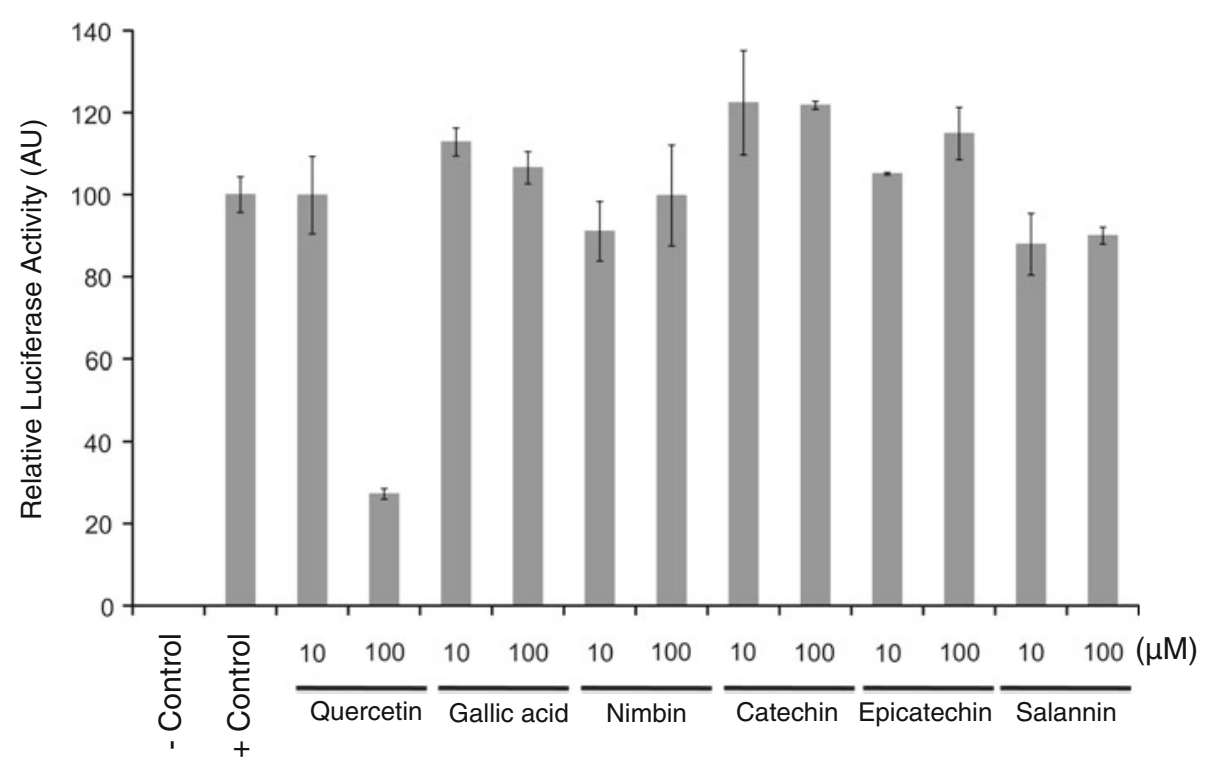

Fig. 1 Effect of pure neem products on the inhibition of TNF- $\alpha$ induced $\kappa \mathrm{NF}-\kappa \mathrm{B}$ activation assessed by a Dual-Glo ${ }^{\mathrm{TM}}$ Luciferase assay system. K562 cells were pretreated with pure compounds at concentrations of 10 or $100 \mu \mathrm{M}$ and incubated for $2 \mathrm{~h}$, followed by TNF- $\alpha$ stimulation for an additional incubation period of $6 \mathrm{~h}$. The results of the luciferase NF- $\kappa \mathrm{B}$ reporter gene assay represented the

reversed-phase column (ZORBAX C18 $21.2 \times 150 \mathrm{~mm}$, $5 \mu \mathrm{m})$ eluting with methanol-water (0:100-100:0) at a flow rate of $1 \mathrm{ml} / \mathrm{min}$ and $U V$ detection $(280 \mathrm{~nm})$. The active compound quercetin in methanolic leaf extract was identified by comparison with pure standard.

\section{Measurement of NF- $\kappa$ B-inhibitory activity}

The inhibitory activity against NF- $\kappa \mathrm{B}$ was determined using a Dual-Glo ${ }^{\mathrm{TM}}$ Luciferase assay system from Promega. Electroporation of K562 cells was realized as described previously [18]. Equal amounts (each $5 \mu \mathrm{g}$ per pulse $\left(2.5 \times 10^{6}\right.$ cells $\left.)\right)$ of an NF- $\kappa \mathrm{B}$ plasmid (Stratagene, $\mathrm{p} 5 \mathrm{xNF}-\kappa \mathrm{B}$ containing five repeats of a consensus $\mathrm{NF}-\kappa \mathrm{B}$ site) and of a Renilla plasmid (phRG-TK, Promega) were added to each pulse. After transient transfection, cells were transferred to culture medium. After $24 \mathrm{~h}$ of incubation, transfected K562 cells were solubilized at a concentration of $1 * 10^{6}$ cells per ml in RPMI 1640 medium containing $0.1 \%$ FCS and $1 \%$ antibioticantimycotic solution and incubated with different concentrations of the neem leaf extract solution. After $2 \mathrm{~h}$ of treatment, TNF- $\alpha$ was added (at $20 \mathrm{ng} / \mathrm{ml}$ ). After 6 additional hours of incubation, expression of NF- $\kappa$ B was assessed according to the provider's protocol by luminescence measurement using a Berthold Orion Luminometer (integration time $10 \mathrm{~s}$ ). ratio of the measured luminescence of the firefly luciferase vector divided by the measured luminescence of the Renilla plasmid. An untreated cell solution was the negative control; positive control was a cell solution treated with TNF- $\alpha$ only. Results were presented as mean and the standard deviation of 4 individual measurements. Experiments were performed in triplicate

Viability assay

The effect of neem leaf extract on cell viability was assessed using the CellTiter-Glo ${ }^{\circledR}$ Luminescent Cell Viability Assay Kit from Promega. The reduction in the number of viable cells in percent was quantified in comparison with a vehicle-treated control according to the manufacturer's instructions.

Electrophoretic mobility shift assay (EMSA)

K562 cells were preincubated with indicated concentrations of neem leaf extract solution. After $2 \mathrm{~h}$ of incubation, $20 \mathrm{ng} / \mathrm{ml}$ of TNF- $\alpha$ was added for additional 6 hours of incubation $\left(37^{\circ} \mathrm{C}, 5 \% \mathrm{CO}_{2}\right)$. Then, nuclear proteins were extracted according to the method of Müller and coworkers [38] and stored at $-80^{\circ} \mathrm{C}$.

The nucleotide $5^{\prime}$-CGCTTGATGACTCAGCCGGA A- $3^{\prime}$ (consensus NF- $\kappa \mathrm{B}$ site) and the complementary sequence were used as probe. Ten micrograms of each nuclear protein extract was incubated for $20 \mathrm{~min}$ at $4^{\circ} \mathrm{C}$ with the ${ }^{32} \mathrm{P}$-labeled probe in a mixture of $15 \mu$ l containing $35 \mathrm{mM}$ of spermidine, $4 \mu \mathrm{M}$ of BSA, and $2.5 \mathrm{mM}$ of polydIdC. In case of a super-shift experiment, the nuclear extract was first incubated with the antibody in the mixture for $15 \mathrm{~min}$ at $4^{\circ} \mathrm{C}$, before the labeled probe was added, followed by an incubation period of $30 \mathrm{~min}$ at $4^{\circ} \mathrm{C}$. Each 
Fig. 2 HPLC diagrams of crude neem leaf extract and pure Quercetin (Fig. 2a, b, respectively)

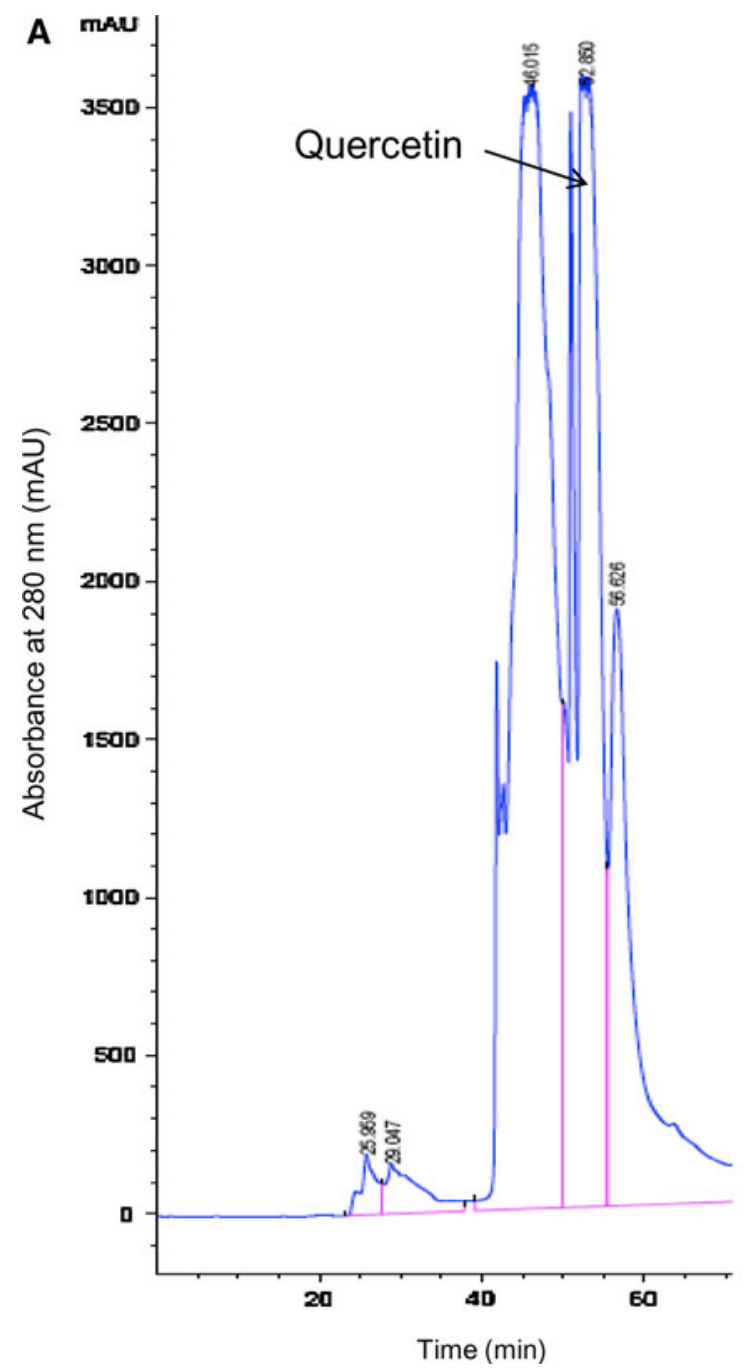

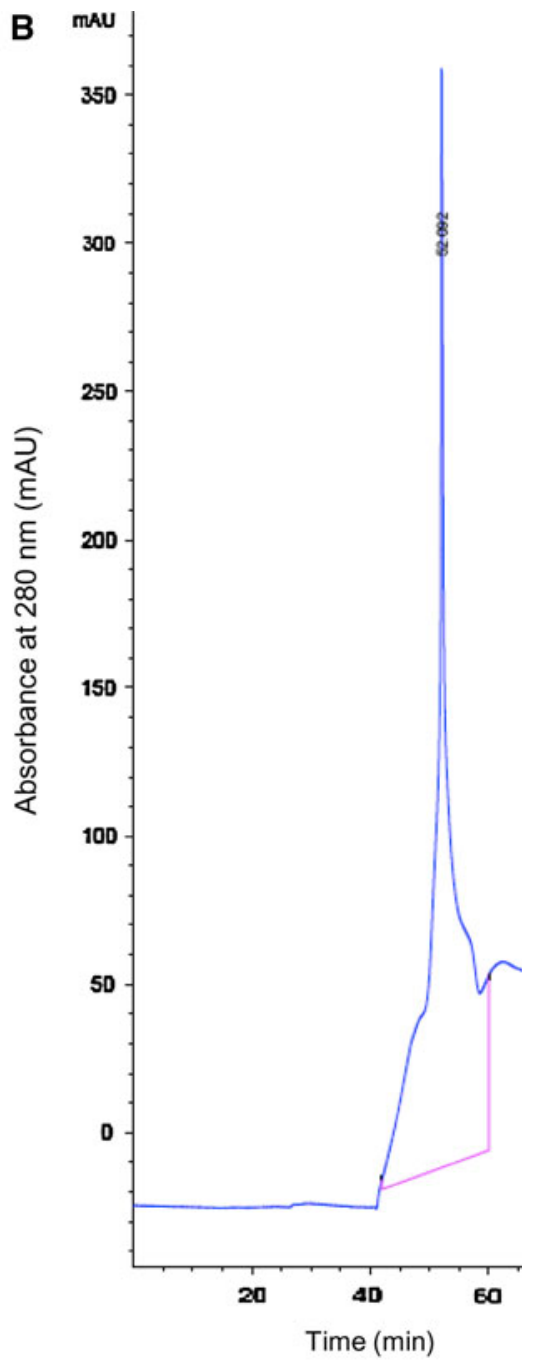

reaction mixture was then loaded with $5 \mu \mathrm{l}$ of loading buffer in a well of the gel, which was pre-run for at least $30 \mathrm{~min}$. The electrophoresis was realized at $16 \mathrm{~mA}$ per gel for at least 2-3 $\mathrm{h}$. The gel was then dried, and the imaging of the signals was performed using a Kodak BioMax XAR film.

\section{Western blot analysis}

After treatment of Jurkat cells with NLE $(300 \mu \mathrm{g} / \mathrm{ml})$ and TNF- $\alpha(20 \mathrm{ng} / \mathrm{ml})$, both $\mathrm{I} \kappa \mathrm{B} \alpha$ degradation and subsequent translocation of p50 or p65 to the nucleus were analyzed in cytosolic and nuclear protein extracts, respectively, by Western blot. In a second set of experiments, K562 cells were treated with different concentrations of NLE. Caspase activation and up-regulation of anti-apoptotic proteins were evaluated through the analysis of total protein extracts. For caspase activation, a positive control was realized by using heteronemin or cisplatin [55, 60]. Cytosolic and nuclear extracts or total protein extraction of the cell lines was performed, and protein concentration of these extracts was determined by Bradford assay and analyzed by Western blot as previously described [13, 18]. Antibodies were from Santa Cruz Biotechnology (p50, p65, I $\kappa$ B, lamin B, $\beta$-actin) Cell Signaling Technologies (Bid, Caspases -3, -7, $-8,-9)$, BD Pharmingen (Bcl-XL, XIAP) and Calbiochem $(\alpha$-tubulin).

\section{IKK kinase activity}

The K-LISA IKK $\beta$ Inhibitor Screening kit from Calbiochem was used for the measurement of the kinase activity. IKK-2 inhibitor IV ([5-(p-fluorophenyl)-2-ureido]thiophene-3-carboxamide) (Calbiochem) was used as a positive control. The assay was performed as indicated in the manufacture's protocol. The absorbance at $450 \mathrm{~nm}$ (with a reference wave length at $590 \mathrm{~nm}$ ) was read using a SpectraCount UV-spectrometer (Canberra-Packard). 

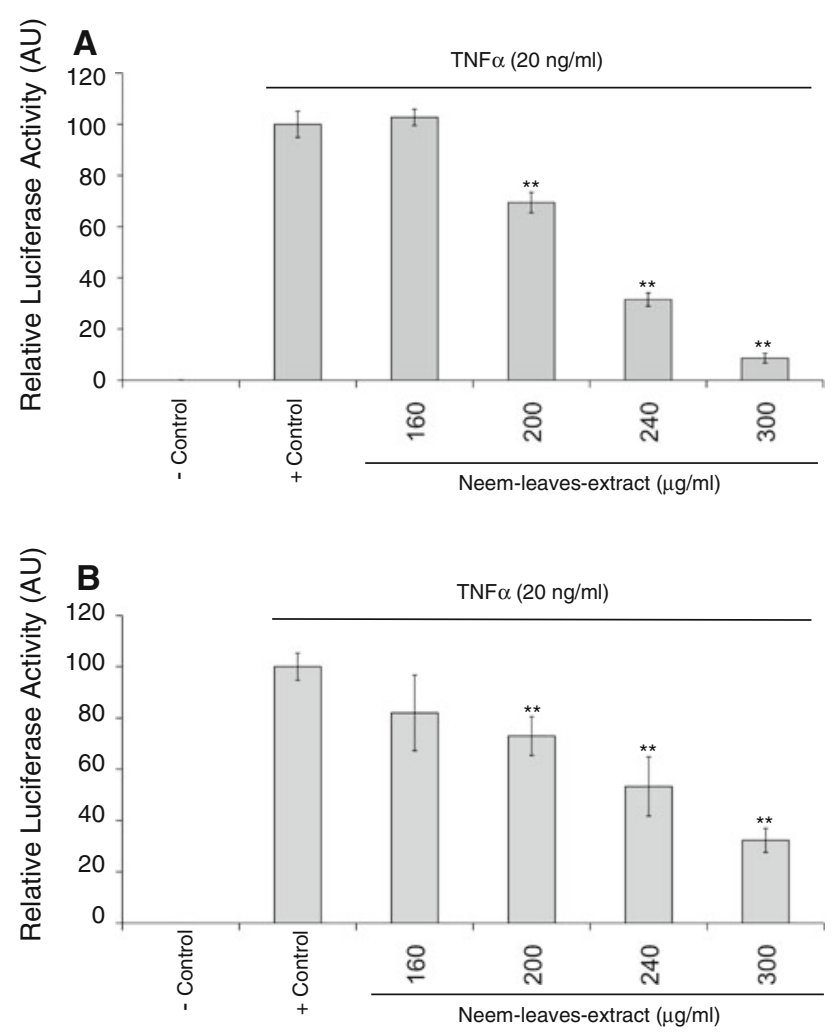

Fig. 3 Effect of neem leaf extract on the inhibition of TNF- $\alpha$-induced NF- $\kappa$ B activation assessed by a Dual-Glo ${ }^{\mathrm{TM}}$ Luciferase assay system. K562 (a) or Jurkat (b) cells were pretreated with neem leaf extract at various concentrations of $160-300 \mu \mathrm{g} / \mathrm{ml}$ and incubated for $2 \mathrm{~h}$, followed by TNF- $\alpha$ stimulation for an additional incubation period of $6 \mathrm{~h}$. Results were presented as mean and the standard deviation of 4 individual measurements. Experiments were performed in triplicate. $*$ and $* *$, significantly different from positive control $(P<0.05$ and 0.01 , respectively)

\section{Analysis of nuclear fragmentation}

The percentage of apoptotic cells was determined through the fraction of apoptotic nuclei via fluorescence microscopy (Leica-DM IRB microscope, Lecuit, Luxemburg) after staining with the DNA-specific dye Hoechst 33342 (Sigma, Bornem, Belgium), as previously described [13]. The fraction of cells with nuclear apoptotic morphology was counted (at least 300 cells in at least three independent fields), and the images were analyzed using the Image $\mathbf{J}$ software (http://rsb.info.nih.gov/ij/docs/index.html).

Flow cytometric analysis

K562 cells were treated with indicated concentrations of NLE for an incubation period of $8 \mathrm{~h}$; then, the cells were assayed for phosphatidylserine exposure, by using the AnnexinV-FITC Apoptosis Detection Kit I® (BectonDickinson Biosciences, Erembodegem, Belgium) as written in the manufacturer's instructions. Stained samples were analyzed by FACS (FACSCalibur, Becton-Dickinson, San José, CA, USA). The data were recorded via the CellQuest software (http://www.bdbiosciences.com/features/ products) for further analysis.

\section{Results and discussion}

Neem leaf extract inhibited TNF- $\alpha$-activated $\mathrm{NF}-\kappa \mathrm{B}$ pathway

$\mathrm{NF}-\kappa \mathrm{B}$ assays of the pure neem standards quercetin, gallic acid catechin, epicatechin, nimbin, and salannin showed that only the product quercetin exerted high $\mathrm{NF}-\kappa \mathrm{B}$ inhibition potential at a concentration of $100 \mu \mathrm{M}$ (Fig. 1). HPLC analysis was done to identify quercetin in methanolic neem leaf fractions. HPLC chromatograms are shown in Fig. 2a. Our results reveal that NLE contains quercetin 4 (52 min) Fig. 2b. This result confirms previous observations as quercetin has been reported to inhibit NF- $\kappa \mathrm{B}$ signaling in murine intestinal epithelial cells [49].

Neem leaf extract (NLE) acts an inhibitor of the TNF- $\alpha$ triggered induction of NF- $\kappa \mathrm{B}$ in our model (Fig. 3) as the activation of the transcription factor was inhibited for more than 80 percent at a dose of $240 \mu \mathrm{g} / \mathrm{ml}$ of the leaf extract. An $\mathrm{IC}_{50}$ of $220 \pm 20 \mu \mathrm{g} / \mathrm{ml}$ (K562) or $250 \pm 20 \mu \mathrm{g} / \mathrm{ml}$ (Jurkat) was calculated using three independent experiments.

Furthermore, binding of NF- $\kappa \mathrm{B}$ to DNA was suppressed after TNF- $\alpha$-triggered activation of the transcription factor when NLE was applied at concentrations between 160 and $320 \mu \mathrm{g} / \mathrm{ml}$ to the CML cell line K562, as shown by EMSA where we observe a decrease in the p50/p65-dimer binding to a consensus NF- $\kappa \mathrm{B}$ binding site (Fig. $4 \mathrm{a}$ ). Immunodepletion experiments proved the identity of the p50/p65 and p50/p50 lanes. (Fig. 4c). Similar results were obtained for neem-treated Jurkat cell lines (Fig. 5).

Over the last years, the use of plant extracts allowed the discovery of various bioactive compounds. Indeed, Moon et al. [37] observed that an aqueous extract of Benincasa hispida Cogniaux reduced $\mathrm{NF}-\kappa \mathrm{B}$ promoter activity in glucose-induced vascular inflammation of human umbilical vein endothelial cells. The extract of the tropical plant Knema laurina (Myristicaceae) was used for centuries for the treatment of digestive and inflammatory diseases and inhibited NF- $\kappa$ B-translocation in brain tissue after inflammatory damage [21]. Lampronti et al. [30] evaluated the inhibitory effects of Bangladeshi medicinal plant extracts on interactions between selected transcription factors and target DNA sequences and discovered that extracts from Terminalia arjuna and Saraca asoka appeared to be most efficient in inhibiting $\mathrm{NF}-\kappa \mathrm{B}$ binding activities. Interestingly, a purified extract called CML-1 was generated from a mixture of 13 oriental herbs widely used for the treatment 

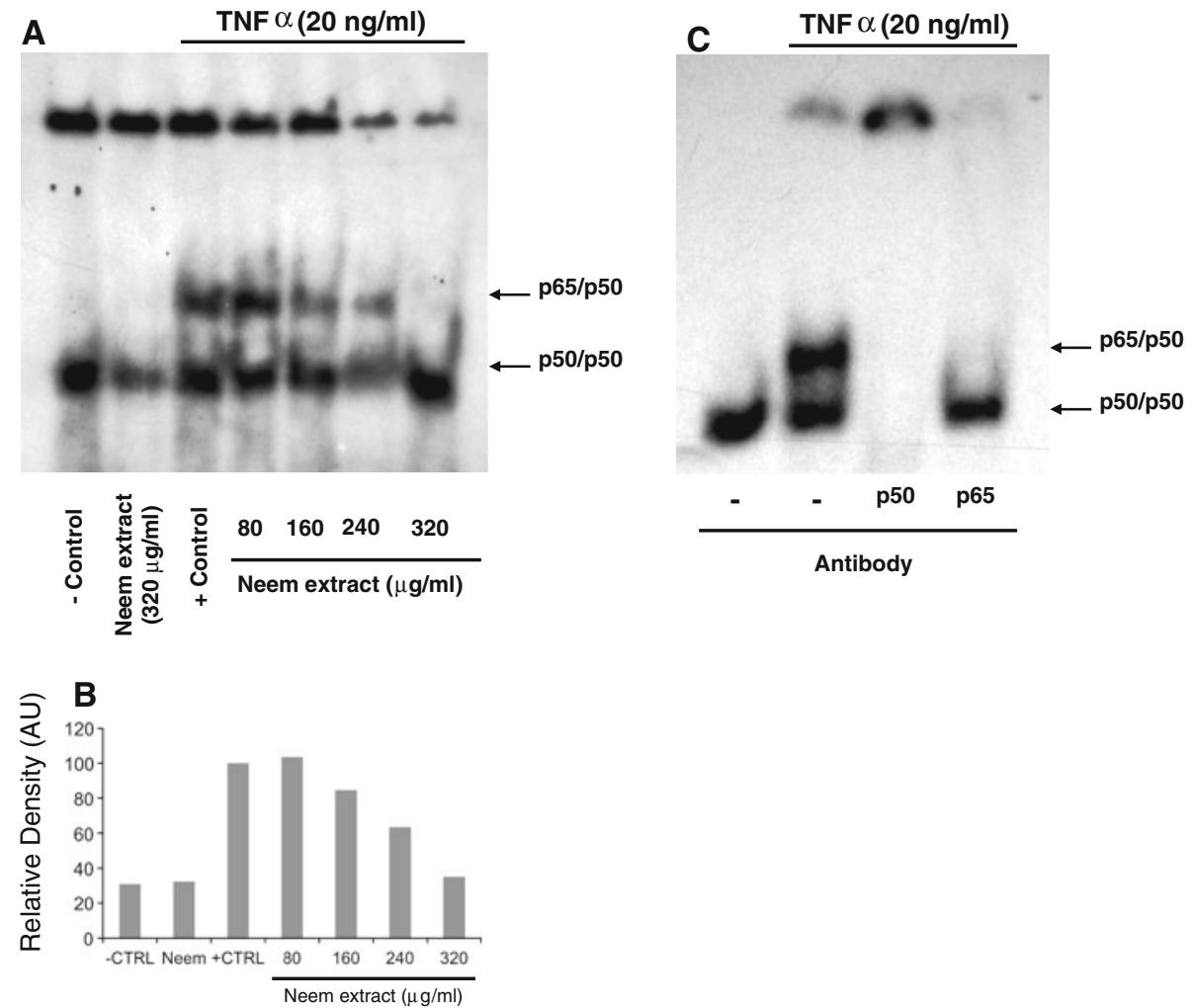

Fig. 4 a Effect of neem leaf extract on the binding affinity of NF- $\kappa$ B assessed by an EMSA. K562 cells were pretreated during $2 \mathrm{~h}$ with different concentrations of neem leaf extract $(80-320 \mu \mathrm{g} / \mathrm{ml})$, followed by TNF- $\alpha$ addition (at $20 \mathrm{ng} / \mathrm{ml}$ ). After additional $6 \mathrm{~h}$ of incubation, the cells were extracted by a method described by Müller and coworkers. [38]. The DNA binding affinity is determined by an incubation of the nuclear cell extract $(10 \mu \mathrm{g})$ with a labeled oligonucleotide probe containing the NF- $\kappa$ B binding site C- $\kappa$ B. b A

of inflammatory diseases in Asia (Achyranthis Radix, Angelicae Gigantis Radix, Cinnamomi Cortex Spissus, Eucommiae Cortex, Glycyrrhizae Radix, Hoelen, Lycii Fructus, Paeoniae Radix, Rehmanniae Radix Preparata and Atractylodis Rhizoma, Zingiberis Rhizoma, Zizyphi Semen, Acori Graminei Rhizoma). This complex mixture inhibits TNF- $\alpha$-induced $\mathrm{I} \kappa \mathrm{B}$ kinase activation, subsequent degradation of $\mathrm{I} \kappa \mathrm{B} \alpha$, and nuclear translocation of NK- $\kappa \mathrm{B}$ that may explain the ability of CML-1 to suppress inflammation [36]. Finally, an extract from stem bark of Cinnamomum cassia Blume (Lauraceae) was discovered to exert an inhibitory effect on lipopolysaccharide (LPS)induced NF-KB transcriptional activity. Following activity-guided fractionation, trans-cinnamaldehyde and 2-methoxycinnamaldehyde were identified as the NF- $\kappa \mathrm{B}$ inhibitors from $C$ cassia with $\mathrm{IC}_{50}$ values of $43 \mu \mathrm{M}$ and $31 \mu \mathrm{M}$, respectively [46].

Several groups reported anticancer, anti-inflammatory, and antioxidant activities of neem tree extracts [20, 34, 54, 57] without providing in-depth analysis of the molecular mechanisms leading to NLE-induced inhibition of NF- $\kappa$ B

quantification of one representative experiment is shown. $\mathbf{c}$ In case of a super-shift/immunodepletion experiment, the nuclear extract was first incubated with the antibody in the mixture for $15 \mathrm{~min}$, before the labeled probe was added, followed by an incubation period of $30 \mathrm{~min}$. Positive control was a cell solution treated with TNF- $\alpha$ only. Negative control was a cell solution with neither TNF- $\alpha$ nor natural compound. The data shown here were representative for three independent experiments with similar results

activation. Accordingly, we compared Jurkat cells treated with TNF- $\alpha$ with or without pretreatment by NLE. Results show in control cells that $\mathrm{I} \kappa \mathrm{B} \alpha$ is degraded after $15 \mathrm{~min}$ of cytokine treatment, followed by the translocation of p50 and p65 to the nucleus (Fig. 6 left panel). However, pretreatment of Jurkat cells with $300 \mu \mathrm{g} / \mathrm{ml}$ of NLE resulted in a complete abrogation of $\mathrm{I} \kappa \mathrm{B} \alpha$ degradation and a significant reduction in nuclear translocation of p50/p65 (Fig. 6 right panel) confirming previous results.

Furthermore, IKK $\beta$ assay showed that NLE significantly inhibited the kinase activity of IKK $\beta$ at a concentration from 160 to $240 \mu \mathrm{g} / \mathrm{ml}$. Moreover, the inhibitory activity of NLE is comparable to the prototypical IKK inhibitor ([5-(p-fluorophenyl)-2-ureido]thiophene-3-carboxamide) provided as a positive control by the supplier (Fig. 7) again confirming previous results.

A number of extracts were described in the literature to efficiently inhibit IKK activity. No results exist so far for neem extracts, but the aqueous extract of Dichroa febrif$u g a$, a medicinal plant well known in China and Korea, inhibits interleukin- $1 \beta$ and interleukin- 6 production in 

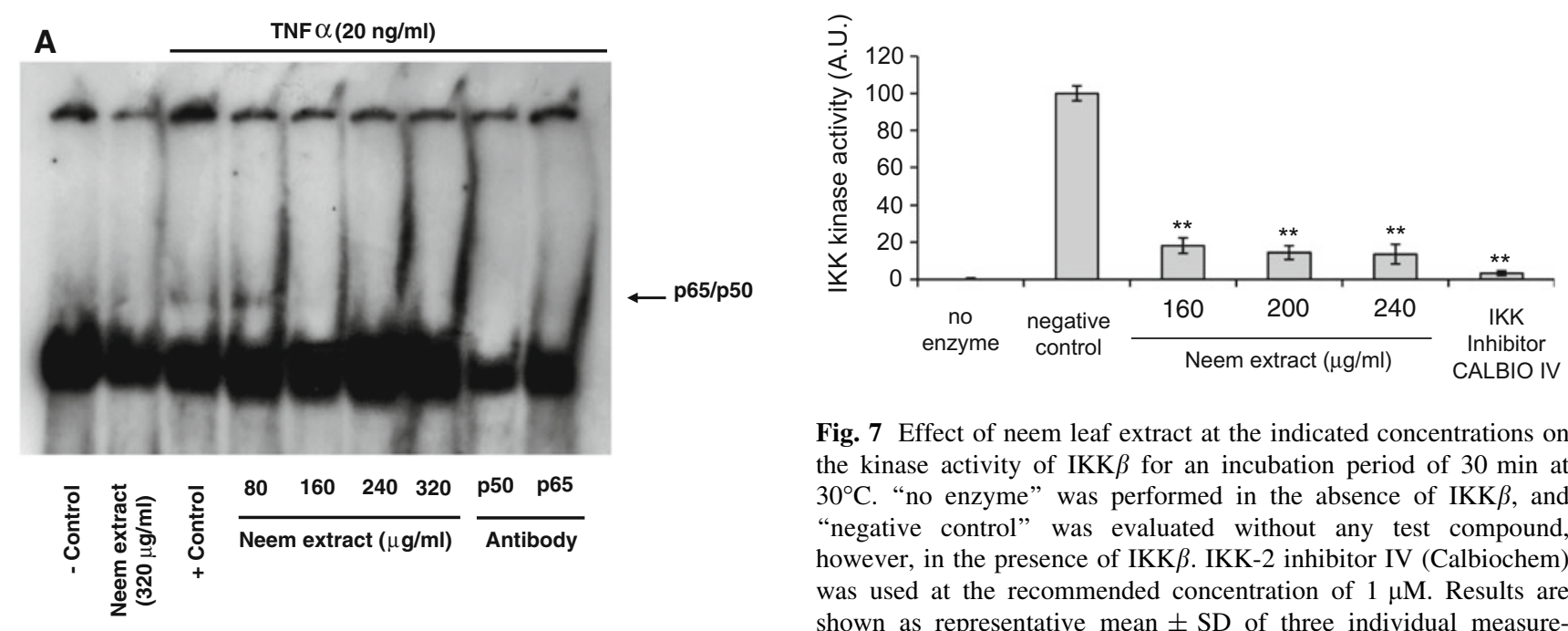

Fig. 7 Effect of neem leaf extract at the indicated concentrations on the kinase activity of $\operatorname{IKK} \beta$ for an incubation period of $30 \mathrm{~min}$ at $30^{\circ} \mathrm{C}$. "no enzyme" was performed in the absence of $\operatorname{IKK} \beta$, and "negative control" was evaluated without any test compound, however, in the presence of IKK $\beta$. IKK-2 inhibitor IV (Calbiochem) was used at the recommended concentration of $1 \mu \mathrm{M}$. Results are shown as representative mean $\pm \mathrm{SD}$ of three individual measurements. * represents $P<0.01$ to the negative control

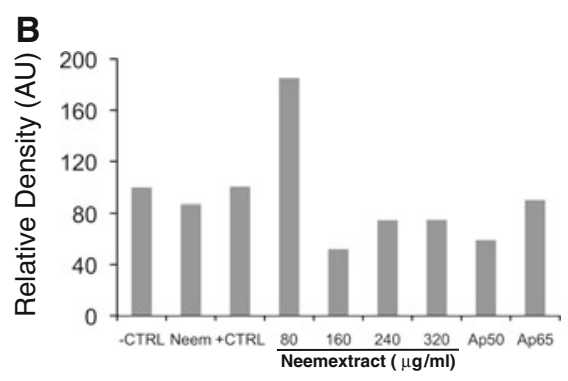

Fig. 5 a Effect of neem leaf extract on the DNA binding affinity of NF- $\kappa$ B assessed by an EMSA on Jurkat cell line. b A quantification of one representative experiment is shown

LPS-stimulated mouse peritoneal macrophages. These effects are mediated by the inhibition of the activity of $\mathrm{IKK} / \mathrm{I} \kappa \mathrm{B} / \mathrm{NF}-\kappa \mathrm{B}$ signaling cascade [42]. Moreover, water-

soluble extracts of Panellus serotinus (Mukitake) powder showed an inhibitory effect on IKK $\beta$, whose activation is required for NF- $\kappa \mathrm{B}$-mediated inflammatory response [40]. Finally, medicinal value of Marasmius oreades was also described as a source for bioactive substances able to induce a direct blockage of NF- $\kappa \mathrm{B}$ activation at the IKK level [43].

Neem leaf extract induced apoptosis in leukemia cells

As there is a clearly documented link between inhibition of the NF- $\kappa \mathrm{B}$ pathway and the induction of apoptotic cell death [1, 2], we assessed whether NLE induces apoptosis in human leukemia cell.

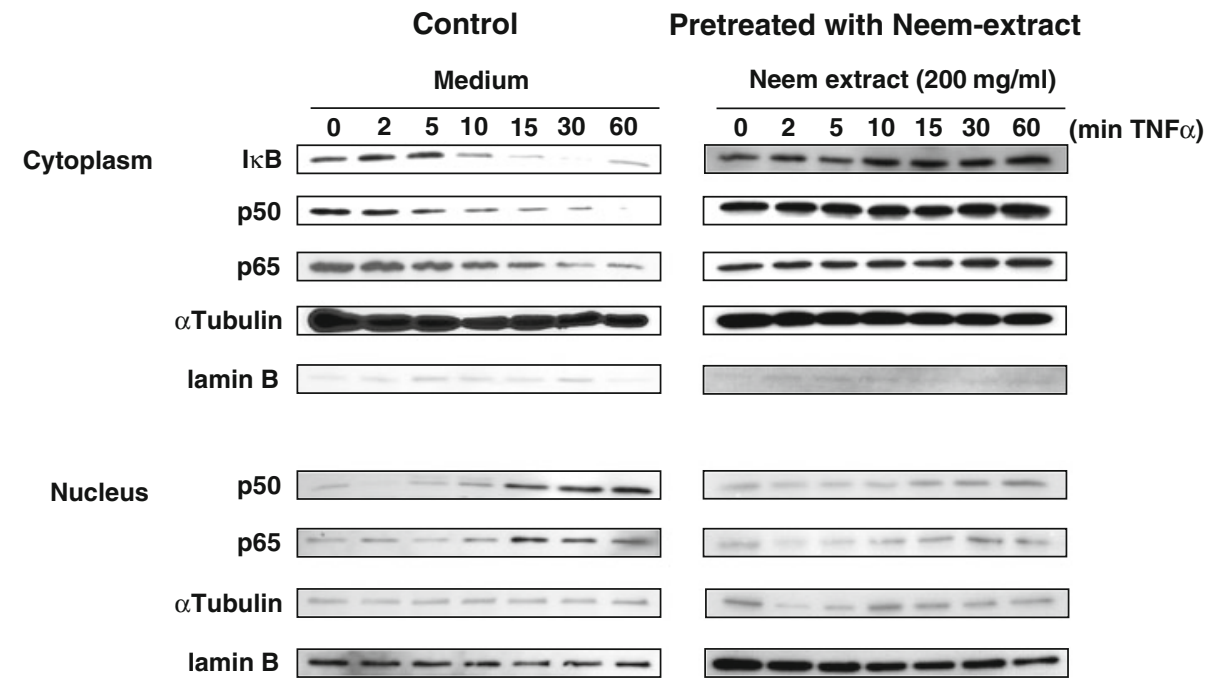

Fig. 6 Effect of neem leaf extract on the degradation of $\mathrm{I} \kappa \mathrm{B} \alpha$ and translocation of p65 and p50 to the nucleus. Jurkat cells were incubated with neem leaf extract (at $300 \mu \mathrm{g} / \mathrm{ml}$ ) for $2 \mathrm{~h}$, followed by a TNF- $\alpha(20 \mathrm{ng} / \mathrm{ml})$ treatment for the indicated time periods. Cytoplasmic and nuclear extracts were prepared, fractionated on a $10 \%$
SDS-page gel, transferred to a membrane, and then tested for $\mathrm{I} \kappa \mathrm{B} \alpha$, p50, p65 (cytosolic) or p50 and p65 (nuclear). Equality of protein loading and purity of nuclear/cytosolic extracts was checked by lamin $\mathrm{B}$ and $\alpha$-tubulin Western blots. The data shown here were representative for three independent experiments with similar results 

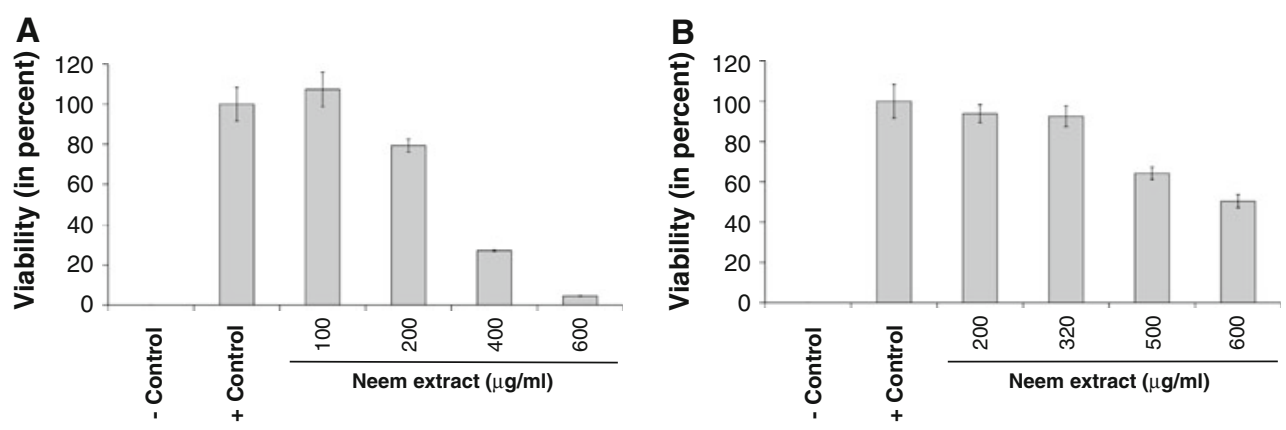

Fig. 8 Viability assay of K562 a and normal PBMCs b treated with indicated concentrations of neem leaf extract for an incubation period of $8 \mathrm{~h}$. Results are shown as representative measurement \pm SD of three independent experiments

Fig. 9 Long-term Viability assay of Jurkat, K562, PC-3, and U937 cells treated with indicated concentrations of neem leaf extract for incubation periods of 24, 48 and $72 \mathrm{~h}$. Results are shown as mean \pm SD of three independent experiments
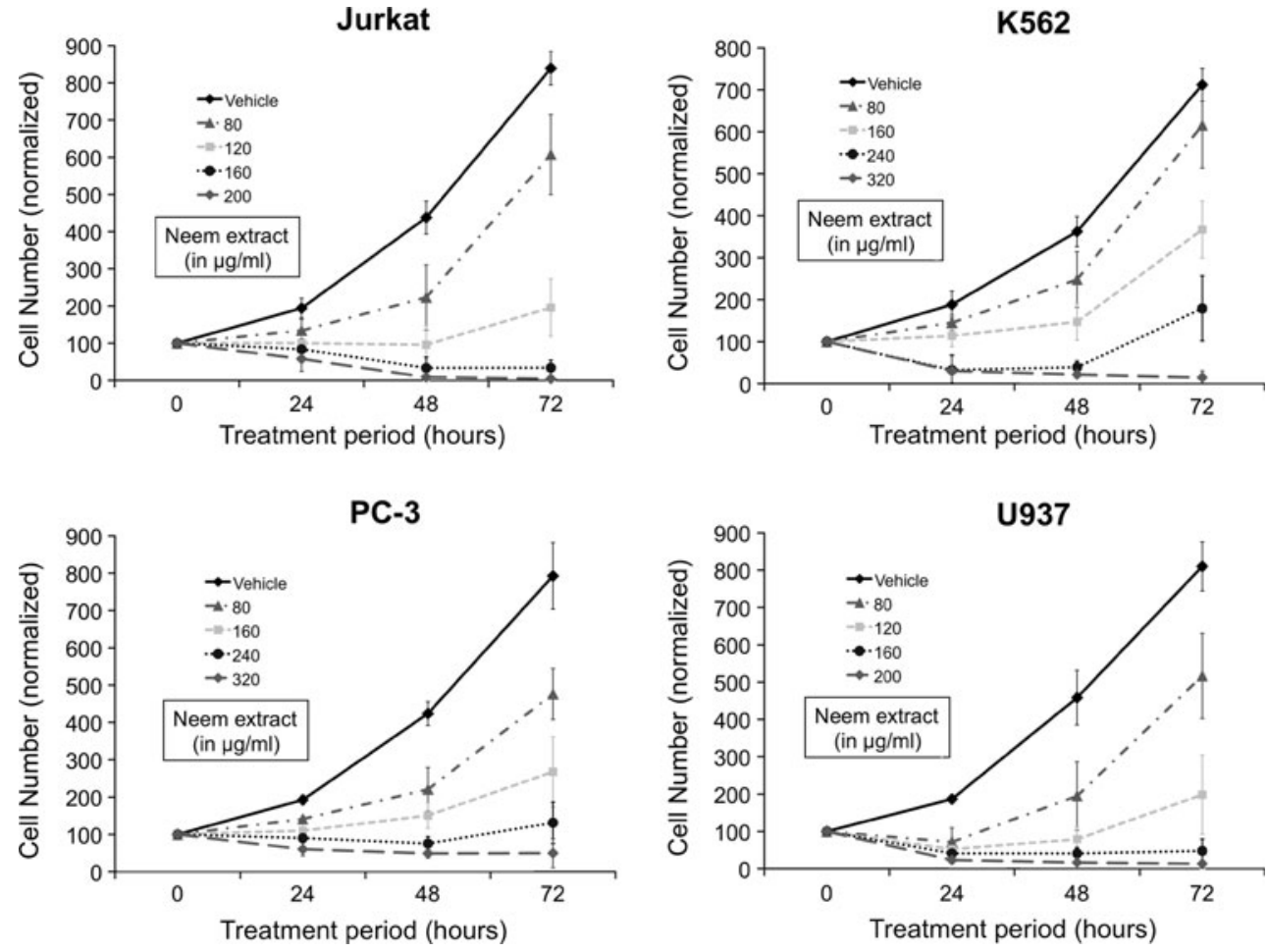

Accordingly, we evaluated the percentage of induction and nature of cell death and found that NLE induced cell death in K562 cells with a $\mathrm{LC}_{50}$ of $300 \pm 20 \mu \mathrm{g} / \mathrm{ml}$ after $8 \mathrm{~h}$ of incubation. At a concentration of $400 \mu \mathrm{g} / \mathrm{ml}$, NLE induced $75 \pm 5 \%$ of cell death to the K562 cell line (Fig. 8a). Interestingly, at concentrations that inhibit NF-kB or induce cell death in cancer cells, healthy PBMCs were not significantly affected by the treatment.

In a next step, we performed a long-term viability assay over 3 days on three different leukemias (K562, Jurkat, and U937) and one prostate cancer (PC-3) cell lines (Fig. 9). K562 showed to be the most resistant cell line, whereas U937 was the most sensitive one (Table 1). At a concentration of $320 \mu \mathrm{g} / \mathrm{ml}$ of neem leaf extract, almost all PC-3 cells and K562 cells were killed, in contrast to Jurkat and U937 cells, for which a concentration of $200 \mu \mathrm{g} / \mathrm{ml}$ was
Table $1 \mathrm{IC}_{50}$ of neem leaf extract in various cell lines after $48 \mathrm{~h}$ of treatment

\begin{tabular}{lc}
\hline Cell line & $\mathrm{IC}_{50}(\mu \mathrm{g} / \mathrm{ml})$ \\
\hline Jurkat & $70 \pm 20$ \\
K562 & $120 \pm 20$ \\
PC-3 & $90 \pm 10$ \\
U937 & $60 \pm 10$ \\
\hline
\end{tabular}

sufficient to reach the same target. These concentrations seem to be very high in contrast to known cancer drugs such as taxol [67]; however, neem leaves are known to be nontoxic to humans, and the pure compound of this extract responsible for this activity will have a lower $\mathrm{IC}_{50}$ (in $\mu \mathrm{M}$ ) than that of the crude extract. 


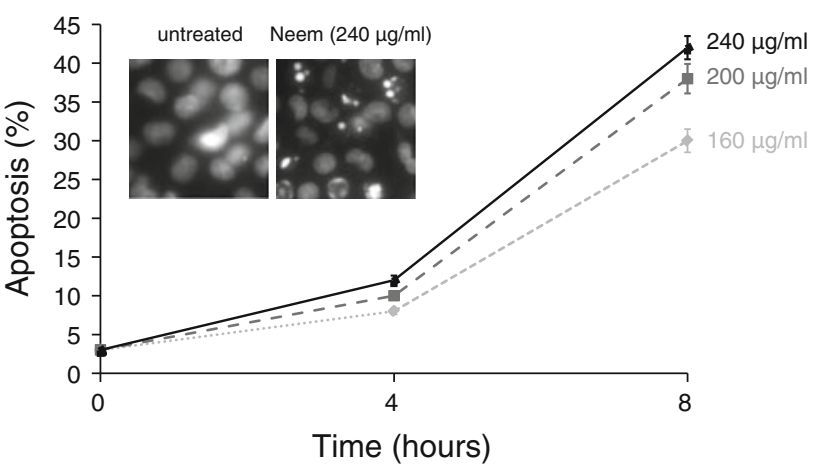

Fig. 10 K562 cells stained with Hoechst to detect nuclear morphology, untreated (left figure) vs. treated with $120 \mu \mathrm{g} / \mathrm{ml}$ of neem extract for $8 \mathrm{~h}$ (right picture), the latter presenting typical fragmented apoptotic nuclei. The graph shows a kinetic analysis of apoptosis induced by neem extract, evaluated as the fraction of cells with apoptotic nuclei stained with Hoechst. The data are the mean of $n=3$ independent experiments $\pm \mathrm{SD}$

In order to determine the precise modality of cell death and mechanisms, we proceeded with nuclear morphology analysis of cells, stained with Hoechst, via fluorescence microscopy. Treated cells clearly displayed apoptotic fragmentation after $8 \mathrm{~h}$ of treatment with $240 \mu \mathrm{g} / \mathrm{ml}$. Figure 10 shows the kinetic evolution of apoptotic cell death induced by NLE and confirmed the data of the viability assay. The flow cytometry analysis clearly indicated that NLE induced a slight level of apoptotic cell death to the K562 cell line with a maximum of 18 percent at a concentration of $240 \mu \mathrm{g} / \mathrm{ml}$ (Fig. 11) with a high number of cells in late apoptosis. Next, we evaluated whether NLE activated a caspase-dependent apoptosis by using Western blot analysis (Fig. 12). Caspase-3, -7, -8, and -9 activation could be observed after $6 \mathrm{~h}$ of treatment at a concentration of $200 \mu \mathrm{g} / \mathrm{ml}$; the sesterterpene heteronemin and the known cancer drug cisplatin were used as positive control $[55,60]$. Additionally, the level of the anti-apoptotic proteins Bcl-xL, Bid, and XIAP was down-regulated after the

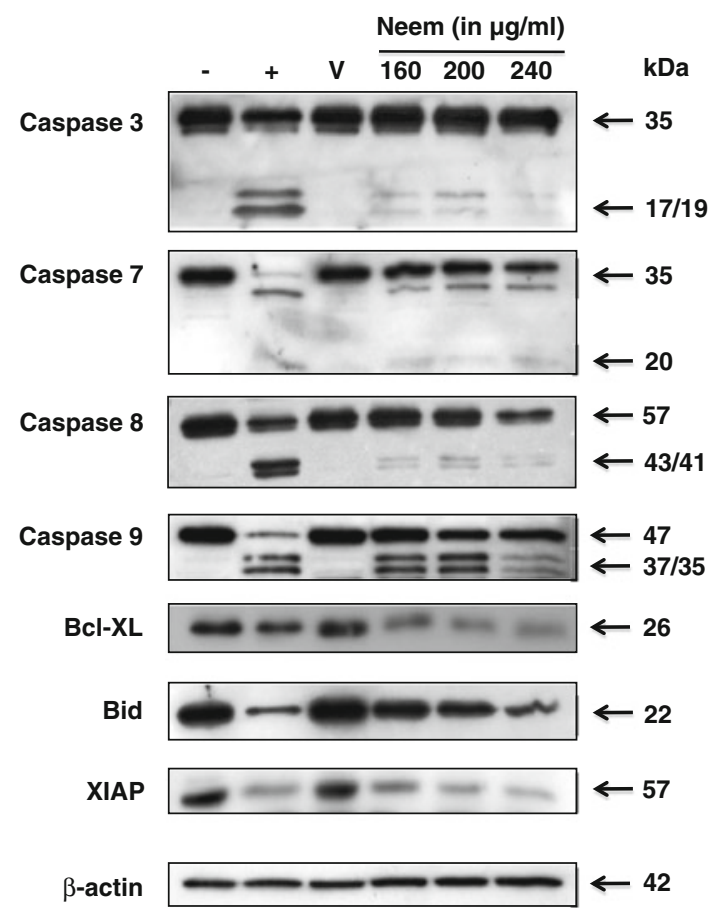

Fig. 12 Analysis of caspase-3, -7, -8, and -9 cleavage and BCL-xL, Bid and XIAP activation by Western blot. Cells were incubated for $8 \mathrm{~h}$ with different concentrations of neem leaf extract, and the activation of the protein was evaluated after $8 \mathrm{~h}$ in comparison with nontreated control (-), a positive control (heteronemin or cisplatin), and a vehicle control (DMSO). Beta-actin was used as a control for protein loading. One representative experiment of three independent ones was shown

identical treatment. These results proved that NLE progressively induced apoptotic cell death most likely via the mitochondrial cell death pathway.

Our results corroborate with published data of an ethanolic neem extract able to induce apoptosis in cancer cells from rodents and men [29, 57]. Interestingly, to the best knowledge of the authors, no effect of neem extract on XIAP was reported in literature; recently, the inhibition of

Neem tree extract

CTRL

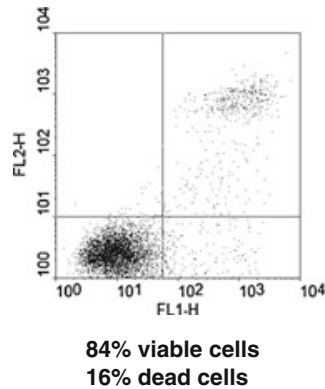

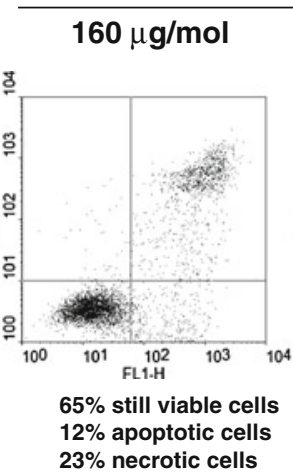

$200 \mu \mathrm{g} / \mathrm{mol}$

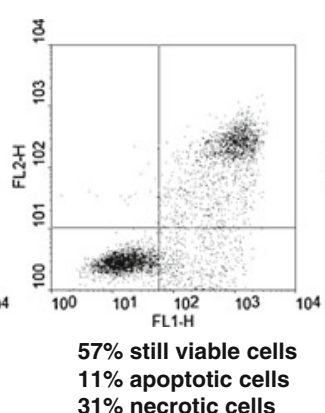

$240 \mu \mathrm{g} / \mathrm{mol}$

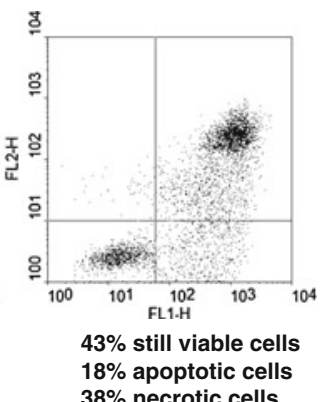

Fig. 11 Apoptotic cells were detected after annexin V-FITC/propidium iodide (PI) staining by FACS. The cells in the lower right quadrant, which are only positive for annexin V, represent early apoptotic cells. One of three independent experiments with similar results is shown 
XIAP emerged as an important cancer drug target $[14,19$, 52]. Similar pro-apoptotic effects were described for extracts from various plants including Physalis minima $\mathrm{L}$. [31], Cassia tora Linn (Leguminacea) [47], Serenoa repens [7], Uncaria rhynchophylla [26], Hibiscus [32], Smilax glabra Roxb. [51], Arnebia nobilis [64], Cimicifuga foetida [65], Brassica oleracea [35], Calendula officinalis [25], Pereskia bleo (Kunth) DC. (Cactaceae) [61], and Catha edulis (Khat) [16].

\section{Conclusion}

Altogether, we show here that NLE acted on different levels of the NF- $\kappa$ B pathway and that it induced apoptosis in leukemia cancer cell. This is, to the best of our knowledge, the first report of these TNF- $\alpha$-induced, anti-inflammatory, and anti-proliferative treatment properties of NLE in human leukemia cancer cell lines. Since the observed effects are beneficial, the extract and its constituents including quercetin might be promising candidates for future studies.

Acknowledgments This work was inspired by Sister Marie-Odile (Evelyne Rehlinger) of the Carmelite Third Order. The authors thank E Henry and J Ghelfi for technical support and Mr Pierre Lutgen for interesting discussion. This work was supported in part by the "Recherche Cancer et Sang" foundation, Télévie and the "Recherches Scientifiques Luxembourg (RSL)" association. M.S., C.C., C.S., and S.R. are supported by a Télévie grant. The authors thank the "Action Lions Vaincre le Cancer" and "Een Häerz fir kriibskrank Kanner" asbl for additional support.

\section{References}

1. Aggarwal BB, Vijayalekshmi RV, Sung B (2009) Targeting inflammatory pathways for prevention and therapy of cancer: short-term friend, long-term foe. Clin Cancer Res 15:425-430

2. Aggarwal BB, Kunnumakkara AB, Harikumar KB, Tharakan ST, Sung B, Anand P (2008) Potential of spice-derived phytochemicals for cancer prevention. Planta Med 74:1560-1569

3. Aggarwal BB, Ichikawa H, Garodia P, Weerasinghe P, Sethi G, Bhatt ID, Pandey MK, Shishodia S, Nair MG (2006) From traditional Ayurvedic medicine to modern medicine: identification of therapeutic targets for suppression of inflammation and cancer. Expert Opin Ther Targets 10:87-118

4. Aladakatti RH, Nazeer Ahamed R, Ahmed M, Ghosesawar MG (2001) Sperm parameters changes induced by Azadirachta indica in albino rats. J Basic Clin Physiol Pharmacol 12:69-76

5. Anand P, Kunnumakkara AB, Harikumar KB, Ahn KS, Badmaev V, Aggarwal BB (2008) Modification of cysteine residue in 065 subunit of nuclear factor-kappaB (NF-kappaB) by picroliv suppresses NF-kappaB-regulated gene products and potentiates apoptosis. Cancer Res 68:8861-8870

6. Arivazhagan S, Balasenthil S, Nagini S (2000) Modulatory effects of garlic and neem leaf extracts on $\mathrm{N}$-methyl- $\mathrm{N}^{\prime}$-nitro-Nnitrosoguanidine (MNNG)-induced oxidative stress in Wistar rats. Cell Biochem Funct 18:17-21
7. Baron A, Mancini M, Caldwell E, Cabrelle A, Bernardi P, Pagano F (2009) Serenoa repens extract targets mitochondria and activates the intrinsic apoptotic pathway in human prostate cancer cells. BJU Int 103:1275-1283

8. Bhanwra S, Singh J, Khosla P (2000) Effect of Azadirachta indica (Neem) leaf aqueous extract on paracetamol-induced liver damage in rats. Indian J Physiol Pharmacol 44:64-68

9. Bhargava KP, Gupta MB, Gupta GP, Mitra CR (1970) Antiinflammatory activity of saponins and ot-her natural products. Indian J Med Res 58:724-730

10. Bose A, Baral R (2007) Natural killer cell mediated cytotoxicity of tumor cells initiated by neem leaf preparation is associated with CD40-CD40L-mediated endogenous production of interleukin-12. Hum Immunol 68:823-831

11. Brahmachari G (2004) Neem-an omnipotent plant: a retrospection. Chembiochem 5:408-421

12. Butterworth JH, Morgan ED (1968) Isolation of a substance that suppresses feeding in locusts. J Chem Soc Chem Commun $4: 23-24$

13. Cerella C, Scherer C, Cristofanon S, Henry E, Anwar A, Busch C, Montenarh M, Dicato M, Jacob C, Diederich M (2009) Cell cycle arrest in early mitosis and induction of caspase-dependent apoptosis in U937 cells by diallyltetrasulfide (Al2S4). Apoptosis 14:641-654

14. Danson S, Dean E, Dive C, Ranson M (2007) IAPs as a target for anticancer therapy. Curr Cancer Drug Targets 7:785-794

15. Dasgupta T, Banerjee S, Yadava PK, Rao AR (2004) Chemopreventive potential of Azadirachta indica (Neem) leaf extract in murine carcinogenesis model systems. J Ethnopharmacol 92:23-36

16. Dimba E, Gjertsen BT, Francis GW, Johannessen AC, Vintermyr OK (2003) Catha edulis (Khat) induces cell death by apoptosis in leukemia cell lines. Ann N Y Acad Sci 1010:384-388

17. Dolcet X, Llobet D, Pallares J, Matias-Guiu X (2005) NF-kB in development and progression of human cancer. Virchows Arch 446:475-482

18. Duvoix A, Delhalle S, Blasius R, Schnekenburger M, Morceau F, Fougere M, Henry E, Galteau MM, Dicato M, Diederich M (2004) Effect of chemopreventive agents on glutathione S-transferase P1-1 gene expression mechanisms via activating protein 1 and nuclear factor kappaB inhibition. Biochem Pharmacol 68:1101-1111

19. Fulda S (2009) Cell death in hematological tumors. Apoptosis 14:409-423

20. Gangar SC, Koul A (2007) Azadirachta indica leaf extract modulates initiation phase of murine forestomach tumorigenesis. Indian J Biochem Biophys 44:209-215

21. Hake I, Schonenberger S, Neumann J, Franke K, Paulsen-Merker K, Reymann K, Ismail G, Bin Din L, Said IM, Latiff A, Wessjohann L, Zipp F, Ullrich O (2009) Neuroprotection and enhanced neurogenesis by extract from the tropical plant Knema laurina after inflammatory damage in living brain tissue. J Neuroimmunol 206:91-99

22. Haque E, Baral R (2006) Neem (Azadirachta indica) leaf preparation induces prophylactic growth inhibition of murine Ehrlich carcinoma in Swiss and C57BL/6 mice by activation of NK cells and NK-T cells. Immunobiology 211:721-731

23. Harish Kumar G, Chandra Mohan KV, Jagannadha Rao A, Nagini S (2009) Nimbolide a limonoid from Azadirachta indica inhibits proliferation and induces apoptosis of human choriocarcinoma (BeWo) cells. Invest New Drugs 27:246-252

24. Harish Kumar G, Vidya Priyadarsini R, Vinothini G, Vidjaya Letchoumy P, Nagini S (2010) The neem limonoids azadirachtin and nimbolide inhibit cell proliferation and induce apoptosis in an animal model of oral oncogenesis. Invest New Drugs 28:392-401

25. Jimenez-Medina E, Garcia-Lora A, Paco L, Algarra I, Collado A, Garrido F (2006) A new extract of the plant Calendula officinalis produces a dual in vitro effect: cytotoxic anti-tumor activity and lymphocyte activation. BMC Cancer 6:119 
26. Jo KJ, Cha MR, Lee MR, Yoon MY, Park HR (2008) Methanolic extracts of Uncaria rhynchophylla induce cytotoxicity and apoptosis in HT-29 human colon carcinoma cells. Plant Foods Hum Nutr 63:77-82

27. Karin M (2006) Nuclear factor-kappaB in cancer development and progression. Nature 441:431-436

28. Ketkar AY, Ketkar CM (2004) Various use of neem products, vol 67. Editor H Schmutterer, Weinheim, pp 518-525

29. Kumar S, Suresh PK, Vijayababu MR, Arunkumar A, Arunakaran J (2006) Anticancer effects of ethanolic neem leaf extract on prostate cancer cell line (PC-3). J Ethnopharmacol 105:246-250

30. Lampronti I, Khan MT, Borgatti M, Bianchi N, Gambari R (2008) Inhibitory effects of Bangladeshi medicinal plant extracts on interactions between transcription factors and target DNA sequences. Evid Based Complement Alternat Med 5:303-312

31. Leong OK, Muhammad TS, Sulaiman SF (2009) Cytotoxic activities of physalis minima L. chloroform extract on human lung adenocarcinoma NCI-H23 cell lines by induction of apoptosis. Evid Based Complement Alternat Med [Epub ahead of print]

32. Lo CW, Huang HP, Lin HM, Chien CT, Wang CJ (2007) Effect of Hibiscus anthocyanins-rich extract induces apoptosis of proliferating smooth muscle cell via activation of P38 MAPK and p53 pathway. Mol Nutr Food Res 51:1452-1460

33. MacKinnon S, Durst T, Arnason JT, Angerhofer C, Pezzuto J, Sanchez-Vindas PE, Poveda LJ, Gbeassor M (1997) Antimalarial activity of tropical Meliaceae extracts and gedunin derivatives. J Nat Prod 60:336-341

34. Manikandan P, Letchoumy PV, Gopalakrishnan M, Nagini S (2008) Evaluation of Azadirachta indica leaf fractions for in vitro antioxidant potential and in vivo modulation of biomarkers of chemoprevention in the hamster buccal pouch carcinogenesis model. Food Chem Toxicol 46:2332-2343

35. Mas S, Crescenti A, Gasso P, Deulofeu R, Molina R, Ballesta A, Kensler TW, Lafuente A (2007) Induction of apoptosis in HT-29 cells by extracts from isothiocyanates-rich varieties of Brassica oleracea. Nutr Cancer 58:107-114

36. Mo SJ, Son EW, Lee SR, Lee SM, Shin DH, Pyo S (2007) CML-1 inhibits TNF-alpha-induced NF-kappaB activation and adhesion molecule expression in endothelial cells through inhibition of IkBalpha kinase. J Ethnopharmacol 109:78-86

37. Moon MK, Kang DG, Lee YJ, Kim JS, Lee HS (2009) Effect of Benincasa hispida Cogniaux on high glucose-induced vascular inflammation of human umbilical vein endothelial cells. Vascul Pharmacol 50:116-122

38. Muller MM, Schreiber E, Schaffner W, Matthias P (1989) Rapid test for in vivo stability and DNA binding of mutated octamer binding proteins with 'mini-extracts' prepared from transfected cells. Nucleic Acids Res 17:6420

39. Murty KS, Rao DN, Rao DK, Murty LBG (1978) A preliminary study on hypoglycaemic and antihyperglycaemic effects of Azadirachta indica. Indian J Pharmacol 10:247-250

40. Nagao K, Inoue N, Inafuku M, Shirouchi B, Morooka T, Nomura S, Nagamori N, Yanagita T (2010) Mukitake mushroom (Panellus serotinus) alleviates nonalcoholic fatty liver disease through the suppression of monocyte chemoattractant protein 1 production in $\mathrm{db} / \mathrm{db}$ mice. J Nutr Biochem 21:418-423

41. Paliwal S, Sundaram J, Mitragotri S (2005) Induction of cancerspecific cytotoxicity towards human prostate and skin cells using quercetin and ultrasound. Br J Cancer 92:499-502

42. Park SY, Park GY, Ko WS, Kim Y (2009) Dichroa febrifuga Lour. inhibits the production of IL-1beta and IL-6 through blocking NF-kappaB, MAPK and Akt activation in macrophages. J Ethnopharmacol 125:246-251

43. Petrova RD, Mahajna J, Wasser SP, Ruimi N, Denchev CM, Sussan S, Nevo E, Reznick AZ (2009) Marasmius oreades substances block NF-kappaB activity through interference with IKK activation pathway. Mol Biol Rep 36:737-744

44. Pillai NR, Santhakumari G (1981) Anti-arthritic and antiinflammatory actions of nimbidin. Planta Med 43:59-63

45. Pillai NR, Santhakumari G (1984) Effects of nimbidin on acute and chronic gastro-duodenal ulcer models in experimental animals. Planta Med 50:143-146

46. Reddy AM, Seo JH, Ryu SY, Kim YS, Min KR, Kim Y (2004) Cinnamaldehyde and 2-methoxycinnamaldehyde as NF-kappaB inhibitors from Cinnamomum cassia. Planta Med 70:823-827

47. Rejiya CS, Cibin TR, Abraham A (2009) Leaves of Cassia tora as a novel cancer therapeutic-an in vitro study. Toxicol In Vitro 23:1034-1038

48. Roy MK, Kobori M, Takenaka M, Nakahara K, Shinmoto H, Isobe S, Tsushida T (2007) Antiproliferative effect on human cancer cell lines after treatment with nimbolide extracted from an edible part of the neem tree (Azadirachta indica). Phytother Res 21:245-250

49. Ruiz PA, Braune A, Holzlwimmer G, Quintanilla-Fend L, Haller D (2007) Quercetin inhibits TNF-induced NF-kappaB transcription factor recruitment to proinflammatory gene promoters in murine intestinal epithelial cells. J Nutr 137:1208-1215

50. Rukmini C (1987) Chemical and nutritional evaluation of neem oil. Food Chem 26:119-124

51. Sa F, Gao JL, Fung KP, Zheng Y, Lee SM, Wang YT (2008) Anti-proliferative and pro-apoptotic effect of Smilax glabra Roxb. Extract on hepatoma cell lines. Chem Biol Interact 171:1-14

52. Salvesen GS, Duckett CS (2002) IAP proteins: blocking the road to death's door. Nat Rev Mol Cell Biol 3:401-410

53. Sanderson K (2007) Chemists synthesize a natural-born killer. Nature 448:630-631

54. Sastry BS, Suresh Babu K, Hari Babu T, Chandrasekhar S, Srinivas PV, Saxena AK, Madhusudana Rao J (2006) Synthesis and biological activity of amide derivatives of nimbolide. Bioorg Med Chem Lett 16:4391-4394

55. Schumacher M, Cerella C, Eifes S, Chateauvieux S, Morceau F, Jaspars M, Dicato M, Diederich M (2010) Heteronemin, a spongean sesterterpene, inhibits TNF alpha-induced NF-kappa B activation through proteasome inhibition and induces apoptotic cell death. Biochem Pharmacol 79:610-622

56. Sen R, Baltimore D (1986) Inducibility of kappa immunoglobulin enhancer-binding protein Nf-kappa B by a posttranslational mechanism. Cell 47:921-928

57. Subapriya R, Bhuvaneswari V, Nagini S (2005) Ethanolic neem (Azadirachta indica) leaf extract induces apoptosis in the hamster buccal pouch carcinogenesis model by modulation of Bcl-2, Bim, caspase 8 and caspase 3. Asian Pac J Cancer Prev 6:515-520

58. Subapriya R, Kumaraguruparan R, Nagini S (2006) Expression of PCNA, cytokeratin, Bcl-2 and p53 during chemoprevention of hamster buccal pouch carcinogenesis by ethanolic neem (Azadirachta indica) leaf extract. Clin Biochem 39:1080-1087

59. Sultana B, Anwar F, Przybylski R (2007) Antioxidant activity of phenolic components present in barks of Azadirachta indica, Terminalia arjuna, Acacia nilotica, and Eugenia jambolana Lam. trees. Food Chem 104:1106-1114

60. Sung B, Pandey MK, Aggarwal BB (2007) Fisetin, an inhibitor of cyclin-dependent kinase 6, down-regulates nuclear factor-kappaB-regulated cell proliferation, antiapoptotic and metastatic gene products through the suppression of TAK-1 and receptorinteracting protein-regulated IkappaBalpha kinase activation. Mol Pharmacol 71:1703-1714

61. Tan ML, Sulaiman SF, Najimuddin N, Samian MR, Muhammad TS (2005) Methanolic extract of Pereskia bleo (Kunth) DC. (Cactaceae) induces apoptosis in breast carcinoma, T47-D cell line. J Ethnopharmacol 96:287-294 
62. Tepsuwan A, Kupradinun P, Kusamran WR (2002) Chemopreventive potential of neem flowers on carcinogen-induced rat mammary and liver carcinogenesis. Asian Pac J Cancer Prev 3:231-238

63. Thakurta P, Bhowmik P, Mukherjee S, Hajra TK, Patra A, Bag PK (2007) Antibacterial, antisecretory and antihemorrhagic activity of Azadirachta indica used to treat cholera and diarrhea in India. J Ethnopharmacol 111:607-612

64. Thangapazham RL, Singh AK, Seth P, Misra N, Mathad VT, Raj K, Maheshwari RK (2008) Shikonin analogue (SA) 93/637 induces apoptosis by activation of caspase-3 in U937 cells. Front Biosci 13:561-568

65. Tian Z, Pan R, Chang Q, Si J, Xiao P, Wu E (2007) Cimicifuga foetida extract inhibits proliferation of hepatocellular cells via induction of cell cycle arrest and apoptosis. J Ethnopharmacol 114:227-233

66. van der Nat JM, van der Sluis WG, t Hart LA, Van Dijk H, de Silva KT, Labadie RP (1991) Activity-guided isolation and identification of Azadirachta indica bark extract constituents which specifically inhibit chemiluminescence production by activated human polymorphonuclear leukocytes. Planta Med 57:65-68

67. Van Quaquebeke E, Simon G, Andre A, Dewelle J, El Yazidi M, Bruyneel F, Tuti J, Nacoulma O, Guissou P, Decaestecker C, Braekman JC, Kiss R, Darro F (2005) Identification of a novel cardenolide ( $2^{\prime \prime}$-oxovoruscharin) from Calotropis procera and the hemisynthesis of novel derivatives displaying potent in vitro antitumor activities and high in vivo tolerance: structure-activity relationship analyses. J Med Chem 48:849-856 